Article

\title{
Sweden and Coronavirus: Unexceptional Exceptionalism
}

\author{
Staffan Andersson ${ }^{1, *}$ and Nicholas Aylott ${ }^{2}$ (D) \\ 1 Department of Political Science, Linnaeus University, SE-351 95 Växjö, Sweden \\ 2 School of Social Sciences, Södertörn University, SE-141 89 Stockholm, Sweden; nicholas.aylott@sh.se \\ * Correspondence: staffan.andersson@lnu.se
}

Received: 19 November 2020; Accepted: 10 December 2020; Published: 15 December 2020

check for updates

\begin{abstract}
The aims of this article are, first, to describe the Swedish authorities' strategy for dealing with the sudden onset of novel coronavirus in early 2020 and, second, to explain why that strategy differed markedly from those in nearly all other European countries. From an early stage, the Swedish government delegated decision making to the Public Health Agency, and its goal was to mitigate the effects of the virus rather than to suppress its spread. Society was never closed down in the same way as elsewhere. Using data from media reports and other publications, we argue that the agency was insulated from pressure to change course, even as the number of deaths associated with covid-19 rose far above those in Sweden's Nordic neighbours, by four conditions: (1) the structure of national public administration; (2) an outburst of nationalism in parts of the media; (3) the uneven impact of the virus; and (4) a political leadership that was willing to delegate responsibility for policy almost entirely. We conclude by briefly comparing the coronavirus strategy to previous episodes of Swedish policy exceptionalism. This emerging pattern, we suggest, raises normative questions about the functioning of Swedish democracy.
\end{abstract}

Keywords: Sweden; coronavirus; strategy; mitigation; media; public administration; delegation; nationalism; leadership; democracy

\section{Introduction}

Sweden stood out from the mainstream as coronavirus swept into Europe in early 2020. Some countries initially planned to contain or mitigate the disease, rather than suppress it. Nearly all of them changed abruptly (and with varying success) to the more common approach of temporarily closing down society, imposing what became known as "lockdown", combined with widespread testing of suspected cases of infection and tracing their contacts. Only Sweden stuck to mitigation.

For sure, it was far from business as usual in Sweden. Social distancing was strongly recommended by the authorities and probably adhered to quite widely by the population during the spring. In comparison to other countries, however, restrictive measures had a light touch. Schools remained open. Children's outdoor activities were curtailed only marginally. Many adults worked more or less as normal. General use of masks to stem the spread of the disease was not recommended. Service and leisure providers such as shops, restaurants, bars and gyms continued to operate. Sweden's relative openness became increasingly the subject of foreign fascination. ${ }^{1}$

1 The Swedish Institute, a public agency that, according to its website, "promotes interest and trust in Sweden around the world", noted this international attention, and the swing between positively and negatively inclined commentary, in various reports (such as, for instance, Svenska Institutet 2020). 
By autumn 2020, the results of Sweden's idiosyncratic strategy were open to a range of interpretations. Several thousand Swedes had died from the virus, mostly in the preceding spring and early summer-a much higher toll than in the other Nordic countries combined. ${ }^{2}$ On the other hand, the negative consequences—economic, social, medicinal—of behavioural restrictions looked likely to be milder in Sweden than elsewhere.

The effectiveness or otherwise of the Swedish strategy is, however, not the main subject of this article. Nor do we discuss the economic measures that the Swedish government used to try to offset the damage done by the pandemic, which were similar to those in other European countries. Our focus is rather on the formulation and implementation of the coronavirus strategy itself. That, too, was undertaken in a notably different way to that found in other countries. Indeed, the fierce criticism that the strategy received during certain periods, both domestically and abroad-the New York Times referred to Sweden as a "pariah state" (New York Times 2020b, June 22)—makes its resilience all the more striking. So too does the fact that the Swedish strategy does not reflect a traditionally libertarian national culture or public health policy (Baldwin 2005, 2020). Sweden in 2020 is thus a deviant case-a methodological status that tends to attract the interest of social scientists (Lijphart 1971).

Our aim, then, is to describe and explain Swedish exceptionalism in respect to coronavirus policy. It can be compared with numerous other examples of Sweden's historical deviation from norms. The "Swedish model" has been debated in various forms, from industrial relations to foreign policy, and from different analytical and normative perspectives (Lane 1991; Pierre 2015a).

In fact, part of our argument is that Swedish exceptionalism, which observers had thought was waning in politics and policy (for example, Pierre 2015b; Rydgren and van der Meiden 2019), may actually be undergoing a resurgence. ${ }^{3}$ Coronavirus induced the second crisis in less than five years, and arguably the third in 11 years, in which Sweden deviated markedly from European policy norms. In 2009, there was the swine flu pandemic, in which Sweden had the most ambitious mass-vaccination scheme in the world. Then there was the wave of migration into Europe that culminated in 2015. Sweden tightened its immigration controls significantly later than other countries did, and only after it had received one-quarter of a million asylum-seekers-equivalent to approximately 2.5 per cent of the national population - in less than two years. There may be a pattern developing; and that pattern raises normative questions about the functioning of the Swedish state and Swedish democracy. We return to these questions in the final section.

Before that, the article develops as follows. We first describe the line taken by the Swedish authorities as the threat of the virus became apparent, and the architects of that line. In this, we focus primarily on the first four months of the crisis, February, March, April and May 2020, although we occasionally refer to events somewhat earlier or later. Our data comprise mostly media reports. The main part of the article involves analysis of the strategy's resilience. We suggest four conditions that insulated the Swedish strategy from pressure to change: the structure of national public administration; the nature of public debate; the uneven impact of the virus; and the prevailing party system and political leadership.

\section{What Was the Swedish Strategy?}

In some ways, the Swedish strategy was not entirely clear. A policy document on the threat of pandemics (primarily influenza), which happened to be published by the Public Health Agency (Folkhälsomyndigheten) in December 2019, defined the goals as to "minimise death and sickness in the population" and to "minimise other negative consequences for individuals and society", through the use of "medicinal ... and non-medicinal measures (such as social distancing)"

2 As of 1 July 2020, the total number of deaths was 6692 in the Nordic countries. In Sweden, it was 5497 (543 per $1 \mathrm{~m}$ of the national population), Denmark 606 (104), Finland 328 (59), Norway 251 (46), and Iceland 10 (29) (Worldometers 2020).

3 One Swedish observer made the opposite interpretation - that the country's corona strategy signalled the end of Swedish exceptionalism (Augustin Palm 2020). 
(Folkhälsomyndigheten 2019, p. 6). ${ }^{4}$ A statement posted in English on the government's website (Government Offices of Sweden 2020b) in early April 2020 about the country's approach to handling coronavirus explained that it sought to "Limit the spread of infection in the country", "Ensure that health and medical care resources are available" and "Limit the impact on critical services". These hint at mitigation rather than suppression; and leading figures within the Public Health Agency were more explicit in affirming that approach (SvD 2020f, May 8).

Anders Tegnell was head of the agency's Department of Public Health Analysis and Data Management. He was also Sweden's chief epidemiologist—or, to translate his title more directly, "state epidemiologist" (statsepidemiolog). In an interview in April, he explained that

we aim to flatten the curve, slowing down the spread [of coronavirus] as much as possible —otherwise the health-care system and society are at risk of collapse ... This is not a disease that can be stopped or eradicated, at least until a working vaccine is produced. We have to find long-term solutions that keeps [sic] the distribution of infections at a decent level (Nature 2020).

Indeed, the longer term was often emphasised by the agency. It argued that the less onerous the restrictions on personal behaviour, the more sustainable they would be.

Initially, the Public Health Agency (Folkhälsomyndigheten 2020c, January 16) judged the risk of coronavirus cases in Sweden to be very low. Only on 25 February did it raise its estimation of the danger of transmission in Sweden, and even then only to low (Eriksson et al. 2020). Tegnell did not think it would happen (AB 2020a, February 26; Karlsten 2020a). He also saw no reason for Swedes to change their travel plans, especially around Stockholm schools' half-term break in the last week of the month, despite the outbreak in Italy at that time. On 7 March, Sweden's entry for the Eurovision Song Contest was decided in front of 27,000 people. Denmark's equivalent, the same evening, was held behind closed doors (Ellingsen and Roine 2020, p. 8). The day after that, Tegnell rejected the requirement in other countries-Denmark, Norway and Finland imposed it between 3 and 16 March (Eriksson et al. 2020, p. 9) - that everyone arriving from places with high rates of infection should self-isolate. Rather, they should do so only if they developed symptoms of covid-19, the sickness caused by coronavirus. The same applied to those living with people who had suspected or even confirmed infections (SvD 2020b, March 9).

Tegnell criticised companies that had already permitted their employees to work from home, on the grounds that it was unfair on workers who could not do so (Expressen TV 2020, March 11). Even before that interview was published, however, the World Health Organisation declared a pandemic and the Public Health Agency announced that, in its view, the risk of transmission in Sweden had become high. According to Tegnell's (2020) retrospective account, the agency's strategy then entered a new phase. It recommended that gatherings of 500 people or more should be prohibited, which the government immediately enacted through a directive. Five days later, Tegnell declared that community transmission was occurring and that people should, in fact, work from home if possible (Radio Sweden 2020, March 16). The next day, the agency urged further- and higher-education providers to switch immediately to remote teaching. ${ }^{5}$

Tegnell described Denmark's decision on 13 March to close its borders as pointless (AB 2020b, March 13). Nevertheless, four days later, on 17 March, the government stopped "non-necessary" travel into Sweden from outside Western Europe, at the EU's request (Government Offices of Sweden 2020a). At the end of March, the limit on gatherings was reduced to 50. Visits to old-age care homes, in which

4 All translations from Swedish-language sources are the responsibility of the current authors.

5 On the same day, 16 March, Finnish colleges, universities, schools and kindergartens were closed. Those in Denmark and Norway had been closed several days before, on 11-12 March (Ellingsen and Roine 2020, pp. 8-9). Also on 12 March, the British government received the analysis that persuaded it to change strategy (Freedman 2020, p. 52). 
infections had taken hold across the country, were also forbidden. A few bars were later closed temporarily for not requiring sufficient distancing between customers.

Otherwise, however, the agency's recommendations remained just that-recommendations, or "nudges", about behaviour, with adherence left to the conscience of the individual (Nature 2020; Pierre 2020). ${ }^{6}$ Swedes were urged to distance themselves from others, especially if they had to travel. People in risk groups, including those over 70, were told to meet others only outdoors and to keep away from crowds. Above all, the basics of hand washing, and of staying at home from work or school in the event of any symptoms, were emphasised. There was little or no compulsion associated with these recommendations. Perhaps most significantly for many people's everyday lives, there was never any directive to close kindergartens and schools. The Public Health Agency referred to the lack of evidence that children spread the virus and the need to keep parents in their workplaces.

From the start of the pandemic, testing for coronavirus was a major feature of some countries' strategies. This was less the case in Sweden (see below). Somewhat later, even as other European countries introduced requirements for masks to be worn in public places (SvD 2020i, August 2), the agency resisted suggestions that masks might be a way of hindering the virus's spread among the general population. ${ }^{7}$

\subsection{Reasoning behind the Strategy}

In sum, while other countries leaned towards the precautionary principle, the Swedish Public Health Agency consistently interpreted the available information about coronavirus in a minimal way, which meant relatively limited intervention in people's lives. Why?

Interestingly, the agency's spokespeople rarely referred to specifically Swedish geographical, social and demographic conditions, such as the country's low population density, small households and good public health, which might have justified a tailored national policy. ${ }^{8}$ Tegnell did assert that "Swedish laws on communicable diseases are mostly based on voluntary measures—on individual responsibility" (Nature 2020), which suggested that the national authorities were constrained. On the other hand, when asked by a British reporter what evidence he had to justify Sweden's strategy, he asked rhetorically what evidence other countries had to justify theirs (PM 2020, April 3). Indeed, Tegnell declared himself "very sceptical of lockdowns" in general. "We can't kill all our services," he reasoned. "And unemployed people are a great threat to public health" (MailOnline 2020, April 4). In a radio lecture in June (Tegnell 2020), he called his agency's coronavirus strategy a "classic" response to an epidemic. The rest of the world, he had thought, seemed to have "gone mad". ${ }^{9}$ Other countries, not Sweden, were pursuing the experiments, he claimed (Reuters 2020, June 25). ${ }^{10}$

Much discussion of the reasoning behind Swedish strategy became concentrated on two distinct issues: infectiousness and post-infection immunity. The agency's positions were, in some ways, contradictory. Yet they had similar policy implications.

The Public Health Agency's initial downplaying of the danger, particularly its refusal to recommend self-isolation for people returning from Alpine holidays, was based on the assumption that people with coronavirus but without symptoms were barely, if at all, infectious (Apuzzo et al. 2020; Skolvärlden 2020, February 28). American and other European authorities already took a more

6 These recommendations (allmänna råd) were, in a sense, legally binding on the individual, yet attracted no sanction if they were broken (Edwards 2020).

7 This, it argued, was due to weak scientific evidence of its usefulness, plus the risk that face masks might detract from the importance of staying at home when symptomatic, washing hands and keeping distance (Folkhälsomyndigheten 2020b).

8 In a report on Sweden, British scientists later did just that (Independent Scientific Advisory Group for Emergencies 2020).

9 As Ellingsen and Roine (2020, pp. 6-7) note, Tegnell had previously published research that was critical of closing schools during an influenza pandemic (Cauchemez et al. 2009). Curiously, that article was co-authored with Neil Ferguson, one of the foremost British advocates of a tough lockdown in the face of coronavirus.

10 Even in the agency's strategy document that had been published in 2019, scepticism towards "non-medicinal measures", about which the findings of research were "not equivocal" (Folkhälsomyndigheten 2019, pp. 20-21), is discernible. 
cautious line (for example, Norwegian Directorate of Health 2020). So too did some Swedish health care professionals and scientists. ${ }^{11}$ In mid-April, Tegnell defended the position of the Public Health Agency in a heated television-debate (Aktuellt 2020, , April 14). The agency reportedly blocked suggestions by the National Board of Health and Welfare that family members of infected individuals should be compensated for self-isolating (Kleja 2020).

Meanwhile, the agency denied that it aimed to achieve "herd immunity", the condition in which enough of a population is immune to a virus-whether through previous infection or distribution of a vaccine-to extinguish its spread. When asked, the authorities acknowledged that widespread immunity might be a by-product of the Swedish strategy, but was not its goal (for instance, SvD 2020c, March 16). At times, however, they sounded more ambivalent.

On 13 March, a former chief epidemiologist, Johan Giesecke, predicted that coronavirus would "sweep through Sweden like a storm" and abate within a couple of months when herd immunity was achieved. Giesecke, who had previously recruited both Tegnell and the director-general of the Public Health Agency during his own time there, was promptly (although quietly) rehired by it, at Tegnell's behest. The two worked closely together (Karlsten 2020c). Giesecke, who maintained a high public profile, later developed publicly his view that it was a mistake to try to suppress a virus so contagious that nearly everyone would get it eventually, often without symptoms. Restrictions on people's behaviour would only delay this spread, not prevent it (Giesecke 2020c; Exp. 2020a, May 6). He made bold and rather varying estimates of how many Swedes had already been infected (Hellberg 2020).

Giesecke's (2020b) view that coronavirus spread like "wildfire" was arguably in conflict with the agency's early dismissal of the idea of transmission by infected but non-symptomatic people. ${ }^{12}$ That latter position implied that the virus was actually less infectious than many, abroad and in Sweden, feared. We infer, therefore, that these two views coexisted within the agency. Proponents of one may have influenced the other, however. Comments by Tegnell in interviews and press conferences during the spring confirmed that, like Giesecke, he regarded rising levels of post-infection immunity among the population-if not necessarily herd immunity, strictly defined-as an important means of bringing the virus under control. ${ }^{13}$ His personal correspondence, as revealed by authors and journalists, provides further evidence (Anderberg 2020; Bjorklund and Ewing 2020; Karlsten 2020b, 2020d). The formula of describing post-infection immunity as desirable, but not a strategic goal, suggests an internal agreement within the agency about how to describe its strategy publicly-although the difference between a goal and a by-product might be considered largely semantic. ${ }^{14}$

In any case, both positions-on infectiousness and on immunity-led logically to a policy of imposing only light restrictions on people's behaviour. Tegnell's scepticism about the infectiousness of non-symptomatic carriers implied that only limited isolation of individuals was needed and that lockdowns were unnecessary (and damaging to other aspects of public health). Giesecke's fatalism about the spread of the virus implied that lockdowns and stricter isolation of individuals were

11 See, for example, Jansson (2020). In early March, a leading Swedish virologist, Fredrik Elgh, urged the Public Health Agency to take account of research into non-symptomatic transmission in its recommendations about self-isolation and protection of the vulnerable and elderly (SR 2020b, March 16; SvD 2020a, March 8; SVT 2020b, March 18).

12 He was initially uncertain about the infectiousness of non-symptomatic carriers (TTELA 2020), but appeared to become persuaded that they would be a major driver of infection (Giesecke 2020b).

13 For instance, Tegnell referred approvingly to Britain's initial strategy (AB 2020c, March 16; Svenska YLE 2020, April 4), and to supposedly high rates of post-infection immunity among Stockholmers (Karlsten 2020b; NRK 2020, April 16), Swedish holidaymakers (SvD 2020g, April 16) and the population in general (The Local 2020, March 31). He argued that other countries, notably Finland, would experience a harsher second wave of the virus than Sweden would, because of Finland's lower levels of immunity (FT 8 May). He made the same argument, this time referring to Denmark, in the autumn (FT 2020b, September 11).

14 In their analysis, Ellingsen and Roine (2020, pp. 5-6) suggest that greater openness about the goal of the strategy could have undermined the agency's plan for a controlled spread of the virus. People, they argue, "may prefer to be infected early rather than engage in costly social distancing if this sacrifice merely delays the infection ... If instead people hold hope that they will be able to avoid the infection altogether, they will be more careful." 
futile. Thus, even if the Public Health Agency's analysis of coronavirus was not entirely coherent, its recommendations could remain stable.

\subsection{Managing the Strategy}

Just as notable as the content of the Swedish strategy was its organisation. The Public Health Agency was created in 2014 through a merger of the Swedish Institute for Communicable Disease Control and the Swedish National Institute of Public Health (Folkhälsomyndigheten 2018). It was given wide responsibility, including the provision of information to underpin decisions by government (such as on travel restrictions) and other state agencies; the dissemination of knowledge to municipalities, regions and other sectors; and the co-ordination of disease control at national level (Ordinance with instruction for the Public Health Agency, SFS 2013, p. 1020). According to the agency's own strategy document on pandemics, its job was, among things, to "monitor the development of the pandemic" and "co-ordinate infection control in Sweden" (Folkhälsomyndigheten 2019, p. 10).

The agency held press conferences on coronavirus almost every day during the spring. Most were led by Tegnell. He gave countless media interviews. He quickly attained an extraordinary level of public recognition. Undoubtedly, Tegnell's prominence reflected the weight of his agency in shaping policy. He did not claim personal control. "Around 15 people from the agency meet every morning and update decisions and recommendations according to the data collection and analysis," he explained in April. "We talk to regional authorities twice per week" (Nature 2020).

In comparative perspective, the remarkable aspect was the absence of political involvement. Ministers repeatedly indicated that they saw their role as to act on requests from the Public Health Agency if and when such requests arrived (SvD 2020d, March 28). Its director-general, Johan Carlson, declared in mid-March that his agency was "holding the baton, very clearly. There has been a lot of pressure from the outside world that we should do different things. But we have an autonomous management of these issues" (Örstadius et al. 2020).

On 22 March the prime minister broadcast a recorded speech to the nation (Löfven 2020). He urged stoicism and warned of coming sacrifice. He emphasised the need to limit the spread of infection, to avoid having many people seriously ill at the same time, and to ensure that resources were available in health care. Otherwise, though, he was unspecific about policy. At the end of March, the government directed the agency to draw up a "national strategy" for testing; but progress was slow. In April, the Swedish parliament granted the government temporary powers to close businesses and other facilities to combat the spread of the virus. Yet even that law arrogated "decisive influence" to the Public Health Agency in decision making, apparently at the agency's own insistence (Kleja 2020). Anyway, the powers were never used.

Löfven insisted in early June that "the government always leads the country and I lead the government" (AB 2020d, June 3). In interviews, however, he often expressed general support for the Swedish strategy, without defending or even describing it in detail (for instance, AB 2020e, July 16; DN 2020b, August 21). When questioned by a German interviewer, another member of the government retorted, "I'm the minister of foreign affairs; I don't know if we have the right science of herd immunity or whatever" (Conflict Zone 2020, June 17), as if the scientific basis of government policy was not her responsibility.

\section{The Resilience of Swedish Strategy}

As we saw above, something resembling what became the Swedish strategy in handling coronavirus could initially be observed in other European countries, too. Only Sweden stuck to it-despite a heavy death toll during the late spring and early summer. This resilience may be as important to understanding this case of Swedish exceptionalism as the ideas that informed it in the first place. We suggest four conditions that, together, explain policy resilience in the case. 


\subsection{The Structure of Public Administration}

The structure of the Swedish state involves extensive delegation. First, there is vertical delegation, from the national to regional and local government. Subnational levels have a major role in policy implementation. ${ }^{15}$ The 21 regions and 290 municipalities are responsible for, respectively, health care and care for the elderly-both of which were at the forefront of the response to coronavirus. Since the 1990s, local and regional authorities have been able to contract out services in these sectors to private operators, which became increasingly commonplace.

Second, there is horizontal delegation, from national government to executive agencies, with the aim of raising efficiency and avoiding "overload" (Jacobsson and Sundström 2016, p. 348). Indeed, Sweden's "East Nordic model" of public administration (Petersson 1994, p. 127) long predates the international trend, which began in the 1980s, towards autonomous agencies (Hall 2016, p. 301; Talbot 2004, pp. 3-4). The Government Offices, which collect the various ministries, have around 4600 employees, of whom 200 are political appointees (Regeringskansliet 2020). Around 263,000 people, meanwhile, work in the 341 agencies (Statskontoret 2020, pp. 11,33), which can issue regulations within their fields of responsibility. The constitution stipulates collective cabinet decision making, which limits the scope for an individual line minister to make important decisions about agencies that are relevant to her area of responsibility. Moreover, ministerstyre-literally translated, "ministerial rule", meaning political interference in individual cases handled by agencies-is prohibited. The independence of the agencies, then, is considerable. Public trust in and satisfaction with most of them is generally high.

Governments give general policy instructions to the agencies. Political direction is issued through the government's budget allocation, legislation, directives and managerial appointments (Ahlbäck Öberg and Wockelberg 2016, pp. 133-34). According to Hall (2016, p. 301), this relatively large distance to street-level bureaucrats is sometimes useful to ministers, who are not responsible for agencies' administrative mistakes, and who can sometimes park inconvenient issues within the bureaucracy. Yet the model is not without problems. Scholars have questioned how realistic it is to separate neatly policy making by politicians and policy implementation by politically neutral bureaucrats, as these tasks are often intertwined. The risk is that defining the role of bureaucrats as isolated from politics "removes them from accountability to the citizenry" (Cooper 2006, p. 54). This became salient in Sweden after the arrival of coronavirus.

With growing fragmentation, through decentralisation and outsourcing, steering and co-ordination in the public sector has become increasingly challenging in Sweden (Möller 2020; Pierre 2020). Like many problems, this one inevitably becomes more acute in a crisis. Difficulties had been apparent in previous episodes, particularly the Asian tsunami in late 2004, in which many Swedes were caught up and hundreds died. There is no special Swedish law on crisis management outside wartime. In response to an inquiry into the tsunami response, however, a Crisis Management Co-ordination Secretariat was set up in 2006 in the Prime Minister's Office. It was moved to the Ministry of Justice in 2014 (Hirschfeldt 2020, p. 1167). This secretariat notwithstanding, one of the Swedish state's lodestars in crisis management remains the "responsibility principle", according to which "those who are responsible for an activity in normal situations also have a corresponding responsibility in the event of a disturbance in society" (MSB 2018, p. 24). Yet that principle does not help much if responsibility is unclear in the first place.

Leading figures within the government and Public Health Agency could acknowledge that co-ordination between and across the public sector, particularly between the national levels and the regional administrations, left much to be desired during the first months of the pandemic (Eriksson et al. 2020, p. 11; SvD 2020e, April 11). This applied especially to testing suspected cases

15 They are responsible for most public services and the major share of public sector employees (54 per cent, 889,000 , in municipalities and 17 per cent, 270,000, in regions) (Ekonomifakta 2020). 
of covid-19 (SR 2020a; SVT 2020a). ${ }^{16}$ Of course, implementation problems in testing were far from exclusive to Sweden. It is, though, possible that such problems incentivised Swedish decision makers to lean towards other, more passive strategies for managing the crisis.

Yet the slow progress may also have reflected the Public Health Agency's lukewarm attitude towards testing. A government-appointed national testing co-ordinator declared, as she resigned after just three weeks in the job, that "in the early phase of the pandemic, Sweden chose a strategy in which testing was not an important part of the battle against the virus". This initial choice, she argued, had impeded the task of building up testing systems in the different regions (DN 2020a, June 3; SvD 2020h, June 4; see also the conflicting claims made in SVT 2020a). It is plausible that the agency's leaders preferred to rely on other tactics-moderate social distancing and rising levels of post-infection immunity-for slowing the spread of coronavirus. Devoting resources to testing and contact tracing makes more sense as part of a strategy of suppression rather than one of mitigation.

The difficulties in establishing a testing apparatus illustrate our argument about the structure of public administration on Sweden's response to coronavirus. Bureaucratic inertia, induced by a combination of autonomous public agencies and unco-ordinated regional health care administrations, insulated the Public Health Agency from political pressure to deviate from its preferred approach. That said, a major part of our argument is that such pressure to change course-which could have emanated from the media, from public opinion, or from political parties, including those in government-never became very strong. We now proceed to examine why that was the case.

\subsection{The Nature of Public Debate on Coronavirus}

Public debate in Sweden can sometimes seem rather constrained. This is not because of formal rules, but rather due to subtler forces. In 2013, a political scientist coined the term "opinion corridor" (åsiktskorridoren), which gained considerable currency. It comprised, he suggested in a blog post, "the buffer zone in which you still have a certain scope to express an opinion without having to field daily diagnoses [from others] about your mental state". This zone, he thought, was "very narrow in Sweden" (Oscarsson 2013).

The Swedish opinion corridor, if it exists at all, should not be overstated. Views expressed by editorial writers and columnists in the four national printed newspapers are wide ranging and debate between them is lively. There is, however, a certain uniformity in news reporting, in which descriptive practices are upheld across publications and broadcast media-and there may be a social cost attached to reporting news in a way that transgresses this uniformity. The opinion corridor was much discussed in Sweden before and after the migration crisis that culminated in 2015; and, in some ways, debate about coronavirus came to resemble that of five years earlier. Much of the left in politics and the media had then defended Sweden's permissive immigration policy. As that crisis grew more acute, the right had increasingly urged policy change-which provoked from the left, in turn, furious accusations of ulterior motives and hidden agendas. As positions on the Public Health Agency's strategy coagulated in early 2020, a comparable alignment could be seen.

Commentators in the newspaper Dagens Nyheter, for instance, in which the editorial line is social liberal (it had long defended the permissive migration policy in 2015), were in 2020 initially sharply critical of the Public Health Agency's approach (Wolodarski 2020) and of the weak political control over policy (Calmfors 2020). At that time, in early March, scientists and doctors associated with epidemiology and virology were publishing frequent op-eds that urged a much more restrictive line.

16 In January, as the world became aware of coronavirus, the agency urged the regions to expand their testing capacity. The response was patchy; a social scientist might see evidence of a collective-action problem (Olson 1965). In mid-March, prompted by the Public Health Agency, the regions restricted tests to hospital patients and staff in health care and elderly care. In mid-April, a fortnight after the government had directed it to do so, the agency did announce its new testing strategy; but it got bogged down in disputes with the Civil Contingencies Agency and was eventually abandoned. Only in June, pushed by the national testing co-ordinator, did the agency declare that all suspected cases of infection should be tested. 
A few weeks later, their increasingly structured collaboration led some of these scientists- "the 22", as they became known - to publish, also in Dagens Nyheter, an intemperate critique of both policy and policy making (Carlson et al. 2020). ${ }^{17}$ These critics provoked counterattacks in the Swedish media that were in some ways similar to those made in 2015, in that they were levelled mainly from the left. In 2020, however, the counterattacks more clearly displayed a strain of Swedish nationalism-what one commentator called "public-health nationalism" (Eriksson 2020).

Defenders of the Public Health Agency often used two main arguments. The first exhibited a reverence for natural science. In fact, though, it may have reflected more a deep, reflexive faith in the capacity and essential goodness of the Swedish state than in science.

In March, commentators chided non-epidemiologists, including a well-known economist and columnist in Dagens Nyheter, for questioning the country's coronavirus strategy. For those commentators, an economist was simply not qualified to criticise the Public Health Agency (Lindberg 2020c). The prime minister, too, later referred dismissively to "amateur epidemiologists" (hobbyepidemiologer) (SvD 2020e, April 11). Indeed, Sweden's exceptionalism in relation to coronavirus was often attributed to Swedish policy being more scientifically grounded than it was elsewhere. Other countries' politicians, it was suggested, had succumbed to pressure induced by public and media panic. Disproportionate and unsustainable policy responses were the result. Giesecke (2020a) referred to politicians' desire to "flex their muscles [visa dåkraft]" and to what had become "almost a competition [among countries] to implement the most drastic measures". The media, he continued, "also play a part" in promoting the spread of unscientific policy, asking "why aren't we doing in our country what they've done in country X?" Tegnell (2020) named Denmark as an example of such a syndrome (also The Local 2020, March 31; FT 2020a, May 8). Senior government officials apparently shared this analysis (Eriksson et al. 2020, p. 8).

Yet there was more to the debate than the role of science in policy making, because not all scientists' views were seen as equally legitimate. There were also accusations from some commentators that criticism of the Public Health Agency amounted to a form of disloyalty or betrayal. In mid-March, Dagens Nyheter was accused by the political editor of Aftonbladet, a left-of-centre newspaper and Sweden's biggest-selling publication, of "undermining public authorities in a crisis" (Lindberg 2020a). Such action, his predecessor as political editor argued, only promoted "populism" (Pettersson 2020)—a clear throwback to the meta-debate in 2015. A well-known scientist attacked Dagens Nyheter's editor for putting himself "on the side of people who, in ever more drastic and polarising terms and with strikingly vague evidence, question the knowledge, research and expertise that exists" (von Schreeb 2020) - as if Swedish public authorities naturally reflected the full range of such knowledge, research and expertise. Some of "the 22", by contrast, were subject to harsh personal attacks in the media (examples are cited in Gustavsson 2020; also Vogel 2020).

The other argument deployed by the Public Health Agency's defenders was in relation to Sweden's people and culture. In other countries, notably Britain, America and, to a degree, Germany (New York Times 2020a, May 18), a lighter-touch approach to managing coronavirus became advocated chiefly on the right. In Sweden, however, it was embraced by the left. This, it was claimed, was because the policy chimed with Swedish values. Aftonbladet's political editor went so far as to attribute to Tegnell, in the epidemiologist's definition of a "recommendation", an encapsulation of "what Swedishness is". Tegnell's "radical message", the editor suggested, was that "the Swedish people can think for themselves ... Quite simply, we want to do the right thing." Most countries had comparable goals in combating the virus, he wrote, but "Sweden's methods are different because we have different traditions, uniquely high trust in each other and a consensus culture in which the team comes before the individual" (Lindberg 2020b). Recommendations rather than laws were thus enough to induce

17 These authors continued their informal collaboration and eventually formalised it through founding the Covid-19 Scientific Forum (Vetenskapsforum covid-19). 
compliance in Sweden and to contain coronavirus. Again, the Public Health Agency reinforced this interpretation. Carlson, its director-general, spoke airily in March of how police in other countries had to "run down the street and hit people and force them inside" (Eriksson 2020).

It is perhaps surprising that the left should celebrate rule by experts and advocate voluntary compliance with public guidelines, but that was how coronavirus was refracted in Swedish public debate in early 2020. Conceivably, this ideological interpretation of the crisis may have given cues to news reporters about how they should describe developments; it is known that a big majority of Swedish journalists leans to the political left (Asp 2012; Lantz 2020). In any case, it was noticeable-not least to foreign correspondents-that Tegnell was usually given a fairly easy time in his press conferences. ${ }^{18}$ His daily briefings were often reported uncritically. Only in May, as Sweden's daily death toll stayed stubbornly high, travel restrictions were imposed on Swedes by the country's Nordic neighbours, and antibody tests appeared to show that fewer Swedes than expected had been infected (and were thus presumably immune to the virus), did the tone of reporting become more questioning of the Public Health Agency. Alternative views began to find space in news reports, not just in op-eds and editorials. Then, as rates of mortality and infection subsided over the summer, reporting reverted to its previous framing.

\subsection{The Effects of the Virus and Public Opinion}

Many national governments experienced a "rally-round-the-flag" effect (Murray 2017) in the early stages of the pandemic, and Sweden was no exception. Swedes' confidence in their institutions rose. Respondents who expressed high confidence in the government rocketed from 34 per cent in autumn 2019 to as high as 65 per cent in the spring 2020 (Andersson and Oscarsson 2020). Opinion polls showed support for the main government party, the Social Democrats, rising dramatically. The Public Health Agency, which had already been one of the Swedish institutions that commanded the highest levels of public confidence, saw its standing becoming even stronger.

In many ways, this was not surprising-even if we disregard the suggestion, offered above, that the national media presented the agency, and Tegnell especially, in a favourable way. Swedes were well aware of the draconian restrictions imposed on people's behaviour in other countries and would naturally have been grateful to avoid being subject to similar measures. Keeping educational facilities open would have been especially popular, given that very few adult Swedes choose not to work, and many are thus reliant on schools and kindergartens for childcare. True, as the daily death toll rose in Sweden during the spring of 2020, and began to stand in stark contrast to the equivalents in neighbouring countries, support for the government, and even the Public Health Agency, did wane somewhat. Yet this decline was never very marked.

Why? We speculate that it may relate partly to the uneven impact of the virus on Swedish society. It is known that, as elsewhere, approximately half the deaths in Sweden of people with covid-19 occurred in care homes. There is also fragmentary evidence that people from ethnic minorities suffered relatively more severely than ethnic Swedes did.

A survey by the Public Health Agency found that taxi drivers, pizza chefs and public-transport workers, jobs that attract large proportions of people with immigrant backgrounds, ran the highest risk of infection between March and May (Folkhälsomyndigheten 2020a). Doctors calculated that, in the same period, deaths among people born in countries from which many refugees had recently migrated to Sweden were 220 per cent higher than the rate in the period 2016-2019 had been. By contrast, there was no increased mortality in Sweden among people aged 40-64 from Europe or North America (the increase was 19 per cent among older people with that background) (Hansson et al. 2020). In late

18 One of those foreign correspondents became known as the "mysterious" or "mad German", whose doggedness in putting critical questions at the Public Health Agency's press conferences, especially about the rejection of transmission by non-symptomatic carriers, distinguished him from his Swedish colleagues (Andén 2020; Exp. 2020b, April 14; Lund 2020). 
June, a journalist pointed to strong correlations between the poorer, immigrant-dominated parts of Stockholm and higher incidence of coronavirus; the richest areas of the city appeared largely untouched (Sundkvist 2020).

It is well known that election turnout among foreign-born Swedish citizens is significantly lower than those born in Sweden (SCB 2019). The same probably applies to party membership. One hypothesis, then, is that there was little pressure exerted through the normal channels of party politics to change coronavirus policy because the most politically engaged people were relatively lightly affected.

\subsection{Politics and Party System}

Sweden is a parliamentary democracy that employs a proportional electoral system. Coronavirus arrived with the country's party system in flux (Aylott and Bolin 2019) and its government commensurately weak.

The party system had become destabilised since 2010, when an eighth party, the far-right Sweden Democrats, had won parliamentary representation for the first time. They were initially ostracised by all the other parties, but their strength was sufficient to prevent either of the mainstream party blocs from winning a parliamentary majority. After the most recent election, in 2018, government formation had proved extremely difficult. The centre-right bloc collapsed, which allowed a minority coalition of Social Democrats and Greens to remain in office. However, there were large policy distances between the government parties, and between them and their new parliamentary partners. A strong, stable government was never likely.

Yet the government's weakness was not directly exposed by the pandemic, because the issue was never much politicised. This may have been partly due to a tradition of political ceasefires (borgfred) during national challenges. For example, even as she was prepared to criticise specific decisions, such as that not to isolate homecoming tourists in February and early March, one centre-right party leader emphasised that she would "lock arms" with the government in the crisis (Ekot 2020, April 25).

Non-politicisation may also have been because of the unexpected support by the Swedish left for light-touch and largely voluntary restrictions. It might have been awkward for economically and socially liberal centre-right parties to advocate stronger, compulsory measures, as, for example, left-of-centre opposition parties did in Britain and the US. The Swedish Greens, too, were disinclined to question what they saw as policy based on scientific evidence (Eriksson et al. 2020, pp. 8-10). From the far right, the Sweden Democrats did urge the sort of response seen in other European countries, including school closures. In early June, the party leader called for Tegnell to resign (Akesson 2020). However, even the Sweden Democrats kept a generally low profile.

In fact, Swedish politics was in flux at another level, too, which may have had more impact on policy.

By 2020, the Social Democrats had governed in Sweden-albeit mostly either as a minority government or with coalition partners or both-for all but 17 years since 1936. Like many of Europe's bigger parties, though, the Social Democrats' electoral fortunes have declined. An election defeat in 2010 induced an acute internal crisis. The party leader resigned. Her replacement lasted just ten chaotic months before he too was forced out. In this desperate moment, the Social Democrats' usual elaborate method of leader selection was set aside. The party's executive committee reportedly offered the job to former ministers who had left politics years before, before turning instead to one of its own members-Löfven, who was then leader of the Metalworkers Union and who had never held any elected political office (Aylott and Bolin 2020). His foremost merit appeared to be his lack of previous association with any particular ideological or strategic orientation within the party.

Over his subsequent years as party leader, during which he became prime minister in 2014, Löfven established himself as an adept political tactician. Not surprisingly, however, given his own credentials and the weak parliamentary basis of his governments, his leadership was largely devoid of significant projects or initiatives. One of his government's first steps had been the move of the 
Crisis Management Co-ordination Secretariat away from the Prime Minister's Office, which some observers interpreted partly as a way of reducing Löfven's exposure to potentially difficult situations (Strömberg 2020). He became a broker of compromises between others, in government and in the parliament. He tended to shun the political limelight, too, to the extent that, by April 2020, as the pandemic intensified, journalists complained about his inaccessibility (Dahlberg 2020b). Given this political background, it is reasonable to suggest that there was little appetite in his government to do anything other than delegate maximally in dealing with coronavirus.

For sure, the government wanted to build up testing capacity. Yet it failed to make that happen. It was, to a degree, obstructed by the fragmented structure of the public sector and the operational independence enjoyed by the Public Health Agency. ${ }^{19}$ Sweden's model of public administration, as discussed above, was thus surely a necessary condition for Sweden's exceptional policy. Yet we contend that it was not a sufficient condition. The government, quite simply, could have pushed harder. Its reactive role was not inevitable.

Back in mid-March, the agency's director-general remarked: "I can well imagine that the government could take the initiative [in decision making] from its side, but that has not been the case." Had his agency been explicitly asked by the government to run things? "Our understanding", Carlson replied, "is that this is the procedure. On the other hand, we have not tried any other procedure." (Örstadius et al. 2020). Indeed, it is not hard to work out a plausible counterfactual scenario, in which, in a national crisis, with the maintenance of public services and thousands of lives and jobs at stake, the political leadership in Sweden had just assumed control of policy-as it had done in various historical crises (Daléus 2012, pp. 209-46) and, belatedly, in the migration crisis five years before. A former auditor-general argued that public-sector fragmentation actually placed a greater onus on the government to take a co-ordinating and steering role. In failing to do so, she argued, it had "abdicated its responsibility" (Ahlenius 2020).

\section{Conclusions}

Crises often illuminate the contours and dynamics of a society. Together, they create the conditions in which external stimuli and shocks are absorbed, and reactions emerge. As almost all European countries were struck by the pandemic at the same time, the differences between their reactions offered some intriguing variation. As we saw, Sweden was exceptional in its response to coronavirus-in more ways than one. Scholars and commentators have already begun to look for deep-seated, sometimes cultural explanations for this latest case of Swedish exceptionalism (Tubylewicz 2020). In this article, we have sought to combine the explanatory force of ideas, and their expression, with the implementation of those ideas through party politics and public administration.

After looking at the evidence, a picture emerges of Sweden's distinct policy emanating first and perhaps foremost from views on how to manage an epidemic, ideas that were established in the Public Health Agency before coronavirus arrived. These views surely depended largely on the convictions and characters of the centrally involved individuals. Crucially, moreover, there was never sufficient pressure on the agency from any quarter to effect change during the initial phase of the pandemic, even as the agency's strategy appeared to be going wrong in late spring 2020. This, we argue, was due to the organisational insulation from political influence that the agency had already acquired; the outbreak of nationalism in media commentary, which, in unpredictable ways, served to protect the agency from criticism; the uneven impact of the virus on Swedish society; and, perhaps above all, the willingness of current political leaders to delegate decision making almost entirely to the agency.

We are not the first to suggest similarities between Sweden's response to coronavirus and its policy in previous crises in recent years (Dahlberg 2020a). Tegnell was involved in the management of the swine flu pandemic in 2009. Sweden was a deviant case then, too-although, interestingly, its response

19 This was the claim made later by the minister of health and social affairs (SVT 2020a). 
in that crisis was more stringent than those in other countries. The decision to try to vaccinate the entire population was not a clear success (Feltelius et al. 2015).

Deviation from the European norm was even more striking in 2015, when Sweden tightened its migration policy long after nearly all other countries had done so. Evaluation of that episode obviously involves more of an ideological value-judgement. Still, empirically, there is certainly something to be explained (Backlund 2020). As in 2020, the impression then was that policy was being shaped not by the government, but by public agencies-in that case, the Migration Agency and the Police Authority-led by strong-willed chief executives. Arguably, this pattern of Swedish exceptionalism raises a normative question about the functioning of Swedish democracy.

Swedish decision makers were certainly capable of self-criticism during the coronavirus pandemic. Yet they doggedly insisted that the basic strategy had been correct. Some went further. Tegnell, in his press conferences and interviews, often sounded determined to defend the Public Health Agency's previous decisions and their results. Sweden's high death toll, for instance, had little or nothing to do with the agency's strategy (Reuters 2020, June 25), but was rather due to specific failings in care homes, Sweden's large immigrant population (New Statesman 2020, October 19) or even to recent mild influenza seasons (DN 2020c). He criticised other countries' coronavirus strategies-which ruffled feathers abroad. ${ }^{20}$ He even offered occasional opinions on other aspects of public policy (Milne 2020).

In short, Tegnell sounded like a politician. Yet when an opposition party called for his resignation, Carlson declared it "remarkable and highly inappropriate to drag the Public Health Agency into the political debate" (SVT 2020c, June 7). Meanwhile, the formal political leadership in Sweden was only marginally involved in shaping strategy. The prime minister and other members of the government sometimes announced relatively minor policy adjustments, but there was no doubt that the important decisions were made by the agency. Exactly who Swedish voters could retrospectively hold accountable for the consequences of this public policy was thus open to discussion.

Sweden's resurgent exceptionalism may, then, be related partly to the national tradition of public administration, including both extensive vertical and horizontal delegation. In recent years, however, this has interacted with additional, contingent factors: weak political leadership and strong bureaucratic leadership. If this model of policy making is perceived as bringing positive results, regarding coronavirus or something else, the problem of accountability might not bother too many people. If policy is perceived to have failed, another crisis—political rather than epidemiological—might ensue in Sweden.

Author Contributions: Both authors contributed to the planning, data collection, drafting and editing. All authors have read and agreed to the published version of the manuscript.

Funding: This research received no external funding.

Conflicts of Interest: The authors declare no conflict of interest.

\section{Abbreviations}

$\begin{array}{ll}\text { AB } & \text { Aftonbladet } \\ \text { Exp. } & \text { Expressen } \\ \text { DN } & \text { Dagens Nyheter } \\ \text { FT } & \text { Financial Times } \\ \text { SvD } & \text { Svenska Dagbladet } \\ \text { SR } & \text { Sveriges Radio } \\ \text { SVT } & \text { Sveriges Television }\end{array}$

20 Karlsten (2020c) recounts frosty exchanges with Norwegian authorities. Another comment by Tegnell about health care capacity led to a fierce response by the Italian ambassador (Ambasciata d'Italia Stoccolma 2020). 


\section{References}

Note: All news reports, which are listed chronologically according to the publication in which they appeared, are from 2020. Reports to which an asterisk $(*)$ are appended were accessed in the printed version of the publication (which may also be available online, although sometimes in slightly different format and with a different date). All others are taken from online versions of the publication. Some are stored behind a paywall. Media articles in which we judge that the author's identity is important, or which feature especially revealing information or insight, are included in the reference list according to the author's name.

AB. 2020a. Tror inte på ett stort utbrott i Sverige. $A B$, February 26. [PubMed]

AB. 2020b. Tegnell om danskbeslut: 'Fullständigt meningslös åtgärd'. AB, March 13. [PubMed]

AB. 2020c. Anders Tegnell hyllar brittisk tanke kring flockimmunitet: 'Dit vi behöver komma'. $A B$, March 16. [PubMed]

AB. 2020d. Regeringen styr riket, jag leder regeringen, vi fattar besluten. $A B$, June 3. [PubMed]

AB. 2020e. Stefan Löfven i stor intervju: 'Svenska coronastrategin rätt'. AB, July 16. [PubMed]

Ahlbäck Öberg, Shirin, and Helena Wockelberg. 2016. The Public Sector and the Courts. In The Oxford Handbook of Swedish Politics. Edited by Jon Pierre. Oxford: Oxford University Press.

Ahlenius, Inga-Britt. 2020. Regeringen har abdikerat. Kvartal, June 9. [PubMed]

Åkesson, Jimmie. 2020. Tegnell måste ta ansvar för misstagen och avgå. DN, June 7. [PubMed]

Aktuellt. 2020. Debate between Anders Tegnell and Lena Einhorn. Aktuellt, SVT, April 14. [PubMed]

Ambasciata d'Italia Stoccolma. 2020. Pressmeddelande från Italiens ambassadör i Sverige Mario Cospito med anledning av ytterligare omtvistliga påstående om hanteringen av Covid-19 i Italien. Stockholm: Ambasciata d'Italia Stoccolma. [PubMed]

Andén, Axel. 2020. Svenska journalister har en del att lära. SvD, June 23.* [PubMed]

Anderberg, Johan. 2020. Mejlen avslöjar Tegnells val: Huvudlös strategi'. SvD, October 8.* [PubMed]

Andersson, Ulla, and Henrik Oscarsson. 2020. Institutionsförtroendet inte lika Politiserat under Pandemin. SOM-Undersökningen om Coronaviruset 2020. Gothenburg: SOM-Institutet and University of Gothenburg. [PubMed]

Apuzzo, Matt, Selam Gebrekidan, and David D. Kirkpatrick. 2020. Behind the curve: How the world missed covid-19's silent spread. New York Times, June 27. [PubMed]

Asp, K. 2012. Journalistkårens partisympatier. In Svenska Journalister 1989-2011. Edited by Ingår i K. Asp. Göteborg: University of Gothenburg.

Augustin Palm, Erik. 2020. Swedish exceptionalism has been ended by coronavirus. Guardian, June 26. [PubMed] Aylott, Nicholas, and Niklas Bolin. 2019. A Party System in Flux: The Swedish Parliamentary Election of September 2018. West European Politics 42: 1504-15. [CrossRef]

Aylott, Nicholas, and Niklas Bolin. 2020. The Rule of the Valberedning? Party Leader Selection in Sweden. In Managing Leader Selection in European Political Parties. Edited by Nicholas Aylott and Niklas Bolin. London: Palgrave.

Backlund, Anders. 2020. Isolating the Radical Right: Coalition Formation and Policy Adaptation in Sweden. Ph.D. dissertation, Södertörn University, Stockholm, Sweden.

Baldwin, Peter. 2005. Disease and Democracy: The Industrialized World Faces AIDS. Berkley: University of California Press. Baldwin, Peter. 2020. Umgang mit Corona: Schweden wählt den entspannten Weg. Berliner Zeitung, April 11. [PubMed]

Bjorklund, Kelly, and Andrew Ewing. 2020. Why the Swedish model for fighting COVID-19 is a disaster. Time, October 14. [PubMed]

Calmfors, Lars. 2020. Politiker-Inte Folkhälsomyndigheten-Behöver ta täten i coronabekämpningen. DN, March 11. [PubMed]

Carlson, Marcus, L. Einhorn, S. Einhorn, F. Elgh, J. Frisùn, Å. Gustafsson, C. Hanson, S. Hanson, O. Isaksson, A. Jansson, and et al. 2020. Folkhälsomyndigheten har misslyckats-nu måste politikerna gripa in. DN, April 14. [PubMed] 
Cauchemez, Simon, Neil M. Ferguson, Claude Wachtel, Anders Tegnell, Guillaume Saour, Ben Duncan, and Angus Nicoll. 2009. Closure of Schools During an Influenza Pandemic. The Lancet Infectious Diseases 9: 473-81. [CrossRef]

Conflict Zone. 2020. Interview with Ann Linde. Conflict Zone, Deutsche Welle, June 17. [PubMed]

Cooper, Terry L. 2006. The Responsible Administrator: An Approach to Ethics for the Administrative Role, 5th ed. San Francisco: Jossey-Bass.

Dahlberg, Anna. 2020a. Sverige vägrar se kriser - förrän läget är extraordinärt. Exp. March 13. [PubMed]

Dahlberg, Anna. 2020b. Löfven kan inte fortsätta ducka för kritiska frågor. Exp. April 30. [PubMed]

Daléus, Pär. 2012. Politisk ledarskapsstil. Om interaktionen mellan personlighet och institutioner i utövandet av det svenska statsministerämbete. Ph.D. dissertation, Department of Political Science, Stockholm University, Stockholm, Sweden.

DN. 2020a. Testkoordinatorn om varför hon slutade: ‘Hade inte det mandatet'. DN, June 3. [PubMed]

DN. 2020b. Löfven: Coronakrisen har skapat stora revor i välfärden. DN, August 21. [PubMed]

DN. 2020c. Tegnells förklaring: Därför dog så många tidigt i Sverige. DN, September 15. [PubMed]

Edwards, Catherine. 2020. Rules or recommendations: Just how strict are Sweden's coronavirus guidelines? The Local, October 21. [PubMed]

Ekonomifakta. 2020. Sysselsättningen i Offentlig Sektor per Kategori år 2018. Available online: https://www.ek onomifakta.se/Fakta/Offentlig-ekonomi/Offentlig-sektor/Sysselsatta-i-den-offentliga-sektorn/ (accessed on 20 October 2020).

Ekot. 2020. Ekots lördagsintervju. 2020 Interview with Ebba Busch. Ekots Lördagsintervju, SR, April 25. [PubMed] Ellingsen, Tore, and Jesper Roine. 2020. Public Policy and the Swedish Model: What was the Swedish Government's Approach to the Pandemic, and How was it Received in Sweden? Stockholm: Stockholm School of Economics, Institute for Research. [PubMed]

Eriksson, Göran. 2020. Folkhälsonationalism ligger bakom det svenska undantaget. SvD, April 28.* [PubMed]

Eriksson, Göran, Jani Pirttisalo Sallinen, and Annie Reuterskiöld. 2020. Regeringens två strider-mot viruset och världen. SvD, July 5. [PubMed]

Exp. 2020a. Giesecke: Alla kommer att utsättas för corona. Exp. May 6. [PubMed]

Exp. 2020b. Tyske journalistens frustration: 'Måste förklara för tyskarna'. Exp. April 14. [PubMed]

Expressen TV. 2020. Interview with Anders Tegnell. Expressen TV, March 11. [PubMed]

Feltelius, Nils, I. Persson, J. Ahlqvist-Rastad, M. Andersson, L. Arnheim-Dahlström, P. Bergman, F. Granath, C. Adori, T. Hökfelt, S. Kühlmann-Berenzon, and et al. 2015. A Coordinated Cross-Disciplinary Research Initiative to Address an Increased Incidence of Narcolepsy Following the 2009-2010 Pandemrix Vaccination Programme in Sweden. Journal of International Medicine 278: 335-53. [CrossRef] [PubMed]

Folkhälsomyndigheten. 2018. Brief Facts and Organization. Public Health Agency Website. Available online: https://www.folkhalsomyndigheten.se/the-public-health-agency-of-sweden/about-us/brief-factsand-organization/ (accessed on 19 October 2020).

Folkhälsomyndigheten. 2019. Pandemiberedskap. Hur vi Förbereder oss—Ett kunskapsunderlag. Stockholm: Public Health Agency. [PubMed]

Folkhälsomyndigheten. 2020a. Förekomst av Covid-19 i olika Yrkesgrupper. Bekräftade Covid-19 fall i Sverige 13 mars-27 maj 2020. Stockholm: Public Health Agency. [PubMed]

Folkhälsomyndigheten. 2020b. "Munskydd", Public Health Agency Website. Available online: https://www.folkhalsomyndigheten.se/smittskydd-beredskap/utbrott/aktuella-utbrott/covid-19/o m-sjukdomen-och-smittspridning/smittspridning/munskydd/ (accessed on 22 September 2020).

Folkhälsomyndigheten. 2020c. Nytt coronavirus upptäckt i Kina. Folkhälsomyndigheten, January 16. [PubMed]

Freedman, Lawrence. 2020. Strategy for a Pandemic: The UK and COVID-19. Survival 62: 25-76. [PubMed]

FT. 2020a. Architect of Sweden's no-lockdown strategy insists it will pay off. FT, May 8. [PubMed]

FT. 2020b. Anders Tegnell and the Swedish Covid experiment. FT, September 11. [PubMed]

Giesecke, Johan. 2020a. Forskare bör hålla sig i sina områden. SvD, March 23.* [PubMed]

Giesecke, Johan. 2020b. The Invisible Pandemic. The Lancet 395: e98. [CrossRef] [PubMed]

Giesecke, Johan. 2020c. De flesta kommer att smittas. SvD, May 7.* [PubMed]

Government Offices of Sweden. 2020a. Ett Tillfälligt Förbud Mot Resor till EU via Sverige med Anledning av Covid-19. Government Website. Available online: https://www.regeringen.se/pressmeddelanden/2020/03/ett -tillfalligt-forbud-mot-resor-till-sverige-med-anledning-av-covid-19/ (accessed on 31 March 2020). 
Government Offices of Sweden. 2020b. Strategy in response to the COVID-19 pandemic. Government Website. April 6. [PubMed]

Gustavsson, Gina. 2020. Has Sweden's coronavirus strategy played into the hands of nationalists? The Guardian, May 1. [PubMed]

Hall, Patrik. 2016. The Swedish Administrative model. In The Oxford Handbook of Swedish Politics. Edited by Jon Pierre. Oxford: Oxford University Press, pp. 299-314.

Hansson, Erik, Maria Albin, Magnus Rasmussen, and Kristina Jakobsson. 2020. Stora skillnader i överdödlighet våren 2020 utifrån födelseland. Läkartidningen 117: 1-4. [PubMed]

Hellberg, Lasse. 2020. Svenska misstagen: Därför dör vi-trots forskarnas varningar. Exp. May 11. [PubMed]

Hirschfeldt, Johan. 2020. Svensk krishantering i fredstid-de konstitutionella aspekterna och en framåtblick. Svensk Juristtidning 2020: 1148-71.

Independent Scientific Advisory Group for Emergencies. 2020. A Closer Look at Sweden's Response to COVID-19. Independent SAGE Report 15. Available online: https://www.independentsage.org/a-closer-look-at-swede ns-response-to-covid-19/ (accessed on 1 October 2020).

Jacobsson, Bengt, and Göran Sundström. 2016. Governing the State. In The Oxford Handbook of Swedish Politics. Edited by Jon Pierre. Oxford: Oxford University Press, pp. 347-61.

Jansson, Anders. 2020. Livsfarliga råd till vården och samhället om risker med coronaviruset. Läkartidningen 117: FZ49. [PubMed]

Karlsten, Emanuel. 2020a. Sant och falskt om vad Folkhälsomyndigheten och Anders Tegnell sagt. Blog Post. 19 March, Updated 27 March. Available online: https://emanuelkarlsten.se/sant-och-falskt-om-vad-statsepide miolog-anders-tegnell-sagt/ (accessed on 7 October 2020).

Karlsten, Emanuel. 2020b. Tegnell: Jag Tror vi uppnår Flockimmunitet Innan Vaccine. Blog Post. April 16. [PubMed]

Karlsten, Emanuel. 2020c. Mejlen som avslöjar Gieseckes inflytande över coronaplanen. Exp. August 11. [PubMed]

Karlsten, Emanuel. 2020d. Det låter som om man är villig att acceptera sjukdom och död. Exp. August 12. [PubMed]

Kleja, Monica. 2020. FHM önskade och fick 'avgörande inflytande' över regeringens beslut. Altinget, September 11. [PubMed]

Lane, Jan-Erik, ed. 1991. “Understanding the Swedish Model". West European Politics 14: 3.

Lantz, Björn. 2020. Partisympatier hos Svenska Journalister 2019_En Kortrapport. Göteborg: Chalmers Tekniska Högskola. [PubMed]

Lijphart, Arend. 1971. Comparative Politics and the Comparative Method. American Political Science Review 65: 682-93. [CrossRef]

Lindberg, Anders. 2020a. Anders Tegnells budskap är att vi kan tänka själva. $A B$, March 29. [PubMed]

Lindberg, Anders. 2020b. Lita på läkare, inte på nätets åsiktsmaskiner. $A B$, March 15. [PubMed]

Lindberg, Anders. 2020c. Många får svårt om inte Sverige misslyckas totalt. $A B$, May 10. [PubMed]

Löfven, Stefan. 2020. Statsminister Stefan Löfvens Tal Till Nationen 22 March 2020. Available online: https://www.re geringen.se/tal/2020/03/statsministerns-tal-till-nationen-den-22-mars-2020/ (accessed on 18 November 2020).

Lund, Lina. 2020. Vem är tysken som ställer Tegnell mot väggen? Dagens Nyheter, March 31. [PubMed]

MailOnline. 2020. Scientist leading Sweden's battle against coronavirus says Britain's lockdown has gone too far as his country allows bars, restaurants and schools to remain open. MailOnline, April 4. [PubMed]

Milne, Richard. 2020. Sweden: Why the 'moral superpower' dissented over Covid-19. FT, October 16. [PubMed]

Möller, Tommy. 2020. En regering ska styra, inte samordna. Kvartal, June 10. [PubMed]

MSB (Myndigheten för samhällsskydd och beredskap). 2018. Gemensamma Grunder för Samverkan och Ledning vid Samhällsstörningar, 4th ed. Stockholm: Swedish Civil Contingencies Agency. [PubMed]

Murray, Shoon. 2017. The "Rally-'Round-the-Flag'" Phenomenon and the Diversionary Use of Force. In Oxford Research Encyclopedia of Politics. Oxford: Oxford University Press. [CrossRef]

Nature. 2020. 'Closing borders is ridiculous': The epidemiologist behind Sweden's controversial coronavirus' strategy. Nature, April 21. [PubMed]

New Statesman. 2020. Sweden's Anders Tegnell: We did not pursue 'herd immunity' against Covid-19. New Statesman, October 19. [PubMed] 
New York Times. 2020a. Germany's Coronavirus Protests: Anti-Vaxxers, Anticapitalists, Neo-Nazis. New York Times, May 18. [PubMed]

New York Times. 2020b. Sweden Tries Out a New Status: Pariah State. New York Times, June 22. [PubMed]

Norwegian Directorate of Health. 2020. Information about Quarantine after Traveling Outside the Nordic Countries. Government Website, March 16. [PubMed]

NRK. 2020. Tegnell: Det kan bli flokkimmunitet i Stockholm i mai. NRK, April 16. [PubMed]

Olson, Mancur. 1965. The Logic of Collective Action. Cambridge: Harvard University Press.

Örstadius, Kristoffer, Mikael Delin, and Karin Eriksson. 2020. Så gick det till när regeringen gav taktpinnen till expertmyndigheten. DN, March 15. [PubMed]

Oscarsson, Henrik Ekengren. 2013. Väljare är inga dumbommar. Blog post. Politologerna, December 10. [PubMed]

Petersson, Olof. 1994. The Government and Politics of the Nordic States. Stockholm: Publica.

Pettersson, Karin. 2020. Dagens Nyheter ägnar sig åt populism. AB, March 15. [PubMed]

Pierre, Jon, ed. 2015a. The Oxford Handbook of Swedish Politics. Oxford: Oxford University Press.

Pierre, Jon. 2015b. Introduction: The Decline of Swedish Exceptionalism? In The Oxford Handbook of Swedish Politics. Edited by Jon Pierre. Oxford: Oxford University Press, pp. 1-18.

Pierre, Jon. 2020. Nudges Against Pandemics: Sweden's COVID-19 Containment Strategy in Perspective. Policy and Society 39: 478-93. [CrossRef]

PM. 2020. Interview with Anders Tegnell. PM, BBC Radio, April 23. [PubMed]

Radio Sweden. 2020. Stockholmers urged to work from home as COVID-19 community spread confirmed. Radio Sweden, March 16. [PubMed]

Regeringskansliet. 2020. Regeringskansliets anställda. Government Offices Website, May 4. [PubMed]

Reuters. 2020. Loved and loathed, Sweden's anti-lockdown architect is unrepentant. Reuters, June 25. [PubMed]

Rydgren, Jens, and Sara van der Meiden. 2019. The Radical Right and the End of Swedish Exceptionalism. European Political Science 18: 439-55. [CrossRef]

SCB (Statistiska centralbyrån). 2019. Analys av Valdeltagande vid de Allmänna Valen 2018. Statistics Sweden. Available online: https://www.scb.se/hitta-statistik/statistik-efter-amne/demokrati/allmanna-val/allmannaval-valdeltagandeundersokningen/pong/statistiknyhet/allmanna-val-valdeltagandeundersokningen-2018/ (accessed on 16 November 2020).

Skolvärlden. 2020. Coronarådet: Finns ingen anledning att stanna hemma trots resor. Skolvärlden, February 28. [PubMed]

SR. 2020a. "Coronapandemin" P1 Dokumentär: Miniserie, episodes released 27 October ("Den dolda smitten"), 3 November ("Den missade testningen"), 10 November ("Testa, testa, testa"). Stockholm: Swedish Radio. [PubMed]

SR. 2020b. “Coronaviruset kan smitta innan du vet att du är sjuk” (interview with Fredrik Elgh), P4 Västerbotten. SR (Sveriges Radio), March 16. [PubMed]

Statskontoret. 2020. Statsförvaltningen i Korthet. Available online: http://www.statskontoret.se/globalassets/publ ikationer/2020/statsforvaltningen_i_korthet_2020_webb.pdf (accessed on 14 July 2020).

Strömberg, Maggie. 2020. Doldisen leder Löfvens krisgrupp—'Som ett krig'. Exp. April 5. [PubMed]

Sundkvist, Frida. 2020. Corona härjar bland fattiga-Rika klarar sig. Exp. June 28. [PubMed]

SvD. 2020a. Virolog: Resenärer från Italien borde stanna hemma. SvD, March 8.* [PubMed]

SvD. 2020b. Epidemiologen: Min bedömning om Kina visade sig inte vara rätt. SvD, March 9. *[PubMed]

SvD. 2020c. Tegnell om flockimmunitet: Tveksamt att experimentera. SvD, March 16.* [PubMed]

SvD. 2020d. Stefan Löfven om 50-gränsen: Nu är det en fråga om folkvett. SvD, March 28.* [PubMed]

SvD. 2020e. Stefan Löfven: Sverige har haft för dålig krisberedskap. SvD, April 11.* [PubMed]

SvD. 2020f. Oense om karantän: 'Viss spridning är acceptabel'. SvD, May 8.* [PubMed]

SvD. 2020g. Tegnell: Svenska turister kan vara säkrare. SvD, May 22.* [PubMed]

SvD. 2020h. Nu är det uppenbart att vi bör testa bredare. SvD, June 4.* [PubMed]

SvD. 2020i. Sverige allt ensammare i munskyddsfrågan. SvD, August 2.* [PubMed]

Svenska Institutet. 2020. Samtalet om Sverige. Rapporteringen om Sverige och Coronapandemin i Internationella Nyhetsmedier och Sociala Medier, 19 August-1 September 2020, Report. Stockholm: Swedish Institute. [PubMed]

Svenska YLE. 2020. Nej, Sveriges strategi är inte flockimmunitet-'Men flockimmunitet är enda sättet att få spridninen att stanna av', säger statsepidemiologen. Svenska YLE, April 4. [PubMed]

SVT. 2020a. Uppdrag Granskning. Stockholm: Swedish Television, November 11. [PubMed] 
SVT. 2020b. 150,000 kan komma att smittas av corona i Västerbotten (interview with Fredrik Elgh). SVT, March 18. [PubMed]

SVT. 2020c. Folkhälsomyndighetens gd till motattack mot Åkesson. SVT, June 7. [PubMed]

Talbot, Colin. 2004. The Agency Idea: Sometimes Old, Sometimes New, Sometimes Borrowed, Sometimes Untrue. In Unbundled Government: A Critical Analysis of the Global Trend to Agencies, Quangos and Contractualisation. Edited by Christopher Pollitt and Colin Talbot. London: Routledge, pp. 3-21.

Tegnell, Anders. 2020. Sommar i P1. Sveriges Radio P1. Stockholm: Swedish Radio, June 24. [PubMed]

The Local. 2020. The Nordic divide on coronavirus: Which country has the right strategy? The Local, March 31. [PubMed]

TTELA. 2020. Experten om coronaläget i Sverige: ‘Tror det blir fler utbrott'. TTELA, March 6. [PubMed] Tubylewicz, Katarzyna. 2020. Sverige har förblivit envist fritt i pandemin. Kvartal, December 1. [PubMed]

Vogel, Gretchen. 2020. 'It's been so, so surreal.' Critics of Sweden's lax pandemic policies face fierce backlash. Science, October 6. [PubMed]

Von Schreeb, Johan. 2020. Wolodarski undergräver svensk expertis. SvD, March 15. [PubMed]

Wolodarski, Peter. 2020. Stäng ned Sverige för att skydda Sverige. DN, March 13. [PubMed]

Worldometers. 2020. Website, Data on Deaths Related to Coronavirus. Available online: www.worldometers.info/ coronavirus (accessed on 7 December 2020).

Publisher's Note: MDPI stays neutral with regard to jurisdictional claims in published maps and institutional affiliations. 